\title{
WEALTH ACCUMULATION AND HOUSING CHOICES OF YOUNG HOUSEHOLDS: AN EXPLORATORY INVESTIGATION
}

Donald R. Haurin

Susan M. Wachter

Patric H. Hendershott

Working Paper No. 5070

\section{NATIONAL BUREAU OF ECONOMIC RESEARCH 1050 Massachusetts Avenue \\ Cambridge, MA 02138 \\ March 1995}

We thank Fannie Mae for support of this research under contract HAU00030W, especially James Carr, Ellen Roche, and Ellis Leslie. Research assistance was supplied by Bongham Kim, EuiChul Chung, and Woo Hyung Yang. We also thank the participants of the Fannie Mae Research Roundtable: "Understanding Household Savings for Homeownership." This paper is part of NBER's research program in Public Economics. Any opinions expressed are those of the authors and not those of the National Bureau of Economic Research.

(C) 1995 by Donald R. Haurin, Susan M. Wachter and Patric H. Hendershott. All rights reserved. Short sections of text, not to exceed two paragraphs, may be quoted without explicit permission provided that full credit, including $\odot$ notice, is given to the source. 


\title{
WEALTH ACCUMULATION AND HOUSING CHOICES OF YOUNG HOUSEHOLDS: AN EXPLORATORY INVESTIGATION
}

\begin{abstract}
This paper describes the wealth accumulation of American youth and relates this behavior to their eventual housing choices. We develop a data set that links wealth profiles of youth with constant-quality house prices and tenure choice. A panel data set is compiled for youth age 2033 for the years 1985 through 1990. We construct wealth profiles for each household over the six year period and indicate how wealth varies with labor supply, marriage, fertility, gender, education, race/ethnicity, and tenure choice. We find renters' wealth accumulates rapidly in the year before and year of first homeownership. The factors related to this increase are marriage, increased labor supply by married women, and gifts/inheritances.

Of particular interest is the finding of an inverse $U$-shaped relationship between the local real price of housing and middle and upper income renters' wealth and married female labor supply. Also, youth in high housing cost localities tend to live in groups at a greater rate compared to those in low cost areas.
\end{abstract}

Donald R. Haurin

Department of Economics and Finance

The Ohio State University

154 North Oval Mall

Columbus, $\mathrm{OH} 43210$

Patric H. Hendershott

Max M. Fisher College of Business

Ohio State University

321 Hagerty Hall

1775 College Road

Columbus, $\mathrm{OH} 43210$

and NBER
Susan M. Wachter

The Wharton School

Finance Department

University of Pennsylvania

Philadelphia, PA 19104 
Table 1: Mean Values of Socio-Demographic Variables in the SCF and NLSY: Respondents Age 24-31

Table 2: Mean Wealth in the SCF and NLSY: Respondents Age 24-31

Table 3: Real Wealth by Age, Longitudinal Profile: $1985-90$

Table 4: Inter-cohort Age-Constant Comparison of Rea1 Wealth: $1985-90$

Table 5: Mean Real Wealth by Eight Categories of Marital History: 1985-90

Table 6: Mean Real Wealth by Eight Categories of Ownership History: 1985-90

Table 7: Mean Married Males' Hours Worked by Eight Categories of Ownership History: 1985-90

Table 8: Mean Married Females' Hours Worked by Eight Categories of Ownership History: 1985-90

Table 9: Mean Fertility by Eight Categorles of Ownership History: 1985-90

Table 10: Mean Household Real Income by Eight Categories of Ownership History: 1985-90

Table 11: Percentage of Households Receiving Gifts or Inheritances by Eight Categories of Ownership History: $1988-90$

Table 12: Range of Constant-Quality Real House Prices-Quartiles: 1985-90

Table 13: Renters' Mean Real Wealth by Three Levels of Aptitude Test Score and Four Categories of Real Constant-Quality House Price: 1985 Distribution of House Prices 
Figure 1: Mean Real Wealth by Gender and Marital Status: $1985-90$

Figure 2: Mean Real Wealth by Race/Ethnicity and Marital Status: $1985-90$

Figure 3: Mean Real Wealth by Four Categories of Highest Grade Completed:

1985-90

Figure 4: Mean Real Wealth by Four Categories of Aptitude Test Score:

$1985-90$

Figure 5: Mean Real Wealth by Four Categories of Respondent's 1990 Labor Supply: 1985-90

Figure 6: Renters' Mean Real Wealth by Four Categories of Real Constant-Quality House Price: 1985 Distribution of House Prices

Figure 7: Homeownership Rates by Four Categories of Real Constant-Quality House Price: 1985 Distribution of House Prices

Figure 8: Renters' Marriage Rates by Four Categories of Real Constant-Quality House Price: 1985 Distribution of House Prices

Figure 9: Real Rental Price of Housing by Four Categories of Real Constant-Quality House Price: 1985 Distribution of House Prices 


\section{Introduction}

Age adjusted homeownership rates of married couples have been declining in the U.S. for more than a decade (Haurin, Hendershott, and Ling, 1988; Haurin and Hendershott, 1988, Office of Policy Development and Research, 1994: Table 21). This decline is most noticeable among young married households (about eight percentage points for those under age 35). For those age 35 to 44 , the decline is much smaller, and for older households, ownership rates are constant or continue to rise.

The change in the national homeownership rate has been relatively modest. Factors tending to reduce the rate include the reduced rate ownership rate of married youth and the decline in the marriage rate; offsetting factors tending to increase the rate include the higher ownership of the older population and the general aging of the population (Hendershott, 1988). However, if the decline in the rate of youth homeownership persists as these households age and replace older households who had higher homeownership rates, the eventual reduction in the national rate will be substantial.

Prior economic analyses of the tenure decision have identified the importance of three economic variables: the relative cost of renting compared to owning, lifetime earnings, and wealth and the associated downpayment constraint (Haurin, Hendershott, Ling, 
1988; Haurin, Hendershott, Kim, 1994; Krumm, 1989). A change in wealth potentially has two effects. Increased current wealth raises lifetime wealth (which also includes the present value of the return to human capital), marginally increasing the tendency to own if ownership is a normal good. On the other hand, additional current wealth relaxes the downpayment constraint, thereby raising the probability of ownership (Jones, 1989). Linneman and Wachter (1989), Zorn (1989), and LaFayette, Haurin, and Hendershott (1994) estimated the impact of mortgage qualification requirements and found wealth to be quite important in determining ownership tendencies. However, these studies were based on cross-sectional data. Conceptually, the accumulation of savings involves intertemporal tradeoffs of consumption and labor supply; thus decisions occur in a multiperiod framework.

Our study links the wealth-tenure choice relationship to other behavior of youth. For example, in areas with a high real constant-quality house price, the required downpayment on a standard house is larger. If a household desires to own, it must save more in high, than in moderate, housing price localities. Other behaviors may change to facilitate savings, including living longer with parents or in a group, delaying fertility, and increasing labor supply. Alternatively, because the downpayment constraint is more difficult to meet in these high 
cost areas, some young households may choose to forego homeownership and thus save less than households in localities with lower housing costs (Yoshikawa and Ohtake, 1989; Sheiner, 1995; Engelhardt, 1994).

The next section of the paper describes the primary data set, the National Longitudinal Survey of Youth (NLSY). The NLSY data are compared to those in the Survey of Consumer Finance and are found to be similar. A secondary data set, derived from American Chamber of Commerce statistics, contains constantquality house prices and rents. In section III, real household wealth for a national sample is reported by age, gender, race/ethnicity, and educational achievement and is then linked to homeownership status, labor supply, real income, and gifts. In section IV, we use a smaller metropolitan areas sample to link real wealth accumulation to real constantquality house prices, homeownership, and other demographic and economic behaviors. Section $V$ highlights the interesting findings.

\section{DATA SOURCES AND MEASUREMENTS}

\section{A. Data Sets}

The scope of this study requires a comprehensive data set containing variables descriptive of the economic/social/demographic characteristics of young households and indicators of local shelter costs. Our basic data set is the National Longitudinal Survey of Youth (NLSY), housed at the Center for Human Resource 
Research, Ohio State University. Beginning in 1979, a national survey of youth age 14-21 was administered to about 10,000 civilian respondents. The retention rate has been about $90 \%$ in subsequent years. Data are collected by personal survey except one was by telephone in 1987 (NLS Handbook, 1993).

The NLSY sample is composed of a general sample and supplemental samples of blacks, Hispanics, and poor whites. These supplements permit more reliable testing of hypotheses related to race/ethnicity and low income. Sample weights are provided each year, allowing statements to be made about the national population of youth. The NLS Handbook discusses details of the sampling methodology and survey design. Although the survey began in 1979, wealth data are reported only in broad categories before 1985, limiting our analysis of wealth accumulation to the period 1985-1990. However, the surveys from 1979 to 1984 contain variables that help in explaining savings behavior, such as measures of race/ethnicity, aptitude, and gender.

Supplemental data on constant-quality house price and rent are obtained for 80 metropolitan areas from the American Chamber of Commerce (ACCRA, 1988). We match survey respondents' counties of residence to these metropolitan areas. This sample covers more cities than the CPI metropolitan area sample and it holds housing quality constant, unlike the National 
Association of Realtors median house price index.

Wealth profiles are studied using two overlapping data sets. The smaller sample, which includes only the 80 metropolitan areas representative of the urban U.S. population, is about one-fourth the size of the larger national sample. If the specific analysis does not require house price information, we use the national sample.

\section{B. Quality of the Data: General}

A number of studies reporting on data quality in the five NLS cohorts have been published. Two have found that panel data are superior to retrospective questioning (Cherlin and Horiuchi 1980; Peters 1988). Morgan (1986) and Bilsborrow and Akin (1982) studied marital status and migration. The aptitude test score was validated by Armstrong, Chalupsky, McLaughlin, and Dalldorf (1988).

Blau and Graham (1990) used NLSY asset data to determine that blacks have substantially smaller wealth than whites at young ages. While Blau and Graham were unable to explain most of this difference, they speculated that inter-generational transfers were important. They did not consider the hypothesis that wealth accumulation is related to the desire for homeownership and the need for a downpayment.

Jianakoplos, Menchik, and Irvine (JMI, 1989) compared longitudinal data on wealth accumulation to 
inferences made from cross-sectional data. They noted that studies of wealth accumulation based on crosssections are possibly severely biased because of changes in earnings capacity over time and because respondent death may create a selective sample. Our focus on young households reduces the bias from occurrences of death, but changes in a cohort's earnings capacity are quite likely during the time when the baby boom generation is moving through the labor force. JMI note that the greatest problem is the bias that could result from attrition. Due to this attrition, they conclude: "plotting the correct (longitudinally based) cohort age-wealth profiles against the cross-sectional age-wealth profiles (which overlap the ages covered) leads to the general conclusion that cross-sectional profiles generally take on grossly incorrect shapes." This should not be a major problem in our study owing to the low attrition rate in our sample.

C. Quality of Data: Wealth

The NLSY reports wealth data annually. Actual amounts are recorded except that large values are censored to protect privacy. Because we delete households with wealth exceeding the truncation points from our sample, the wealth profiles are not overly influenced by a few extraordinarily wealthy households. (Truncation values, identical in all years, are listed in Appendix A.) 
Prior studies of labor supply and housing demand have used NLSY wealth data as an explanatory variable. $^{1}$ No problems of reliability have been noted. However, because wealth data are the focus of our study, we conduct a further test by comparing these data with those from the Survey of Consumer Finance. This comparison requires matching survey year (1989), age ranges, and wealth categories. Means of weighted national data are derived and compared. As of January 1, 1989, the respondents in the NLSY were age 24-31 (about equal numbers of men and women); but the spouse could be any age. The NLSY does not identify heads of household; rather, the unit of analysis is a respondent. The SCF reports the age of both the head of household and spouse. To insure the households in the two data sets are comparable in age range, we select all SCF households where either head or spouse is age 24-31. To make the wealth data comparable, we imposed the same truncation rules on data from both sources. ${ }^{2}$

To confirm the similarity of the two data sets, we first compare the means of a set of socio-demographic variables. The results, reported in Table 1, are generally supportive of the conclusion that the two samples, size 367 for the SCF and 7946 for the NLSY, are drawn from the same population. (None of the differences in means are statistically significant.) We note that the SCF sample has a modestly higher proportion of married couples and homeowners, 
suggesting that the reported mean level of wealth will be marginally greater than the average in the NLSY.

The mean levels of wealth for households in the two data sets are reported in Table 2. Categories of various asset types could not be precisely matched in the SCF and NLSY because of differences in survey questions. For similar questions, such as homeowners' house value and debt, the results of the two surveys are remarkably similar. In the SCF, homeowner's mean house value is $\$ 56,952$ and mean house debt is $\$ 41,622$. In the NLSY, the comparable values are $\$ 56,282$ and $\$ 40,127$. The only difference that is statistically different at the 0.05 level is for liquid wealth and that is likely explained by differences in categorization. (The categories are mutually exclusive; wealth is net, current value less debt.) Mean wealth is about 108 larger in the SCF, well within sampling variation. This difference is consistent with the previously noted difference in percent married and homeowners. We conclude that the NLSY asset data are reliable.

The last row in Table 2 reports the mean amount of gifts received by respondents in the prior year. This variable may be important in explaining the occurrence of first homeownership because it includes gifts from parents. Again, the means of the two samples are similar. 


\section{D: House Rent and Price Indexes}

The American Chamber of Commerce (ACC) is the basic source of the constant-quality metropolitan rent series in the sampled years. We use a sample of 80 metropolitan areas. ${ }^{3}$ Annual averages are means of quarterly data. Rent is the monthly rental for a two-bedroom, one-and-a-half bathroom, 950 square foot unfurnished apartment. Utilities are excluded except water. A comparison of these data for 28 areas in 1988 with the rent index by Moulton (1989) yields a correlation coefficient of 0.81 .

Our house price series is also obtained from the ACC. The standard house has 1,800 feet of 1 iving area and 8,000 square feet of land with three bedrooms and two baths. In addition, 23 other characteristics that specify the quality of the house are listed in ACCRA (1988) and are held constant in cross-metropolitan comparisons. The correlation of these data for the period 1985-90 with the house price index developed by Haurin, Hendershott, and Kim (1991) is 0.73.4

Nominal variables vary both over time and across space. We control for both by deflating using the panel data set of state deflators reported in McMahon (1991) covering 1985-1990.5

\section{E: Socio-Demographic Variables}

Other variables used in this study are derived from responses to survey questions in the NLSY (NLS 
Handbook, 1993). All nominal values are deflated.

Information on income is for the prior calendar year. Other data are reported as of the survey date, which typically occurs in the first quarter of the year.

F. Construction of Wealth Profiles

Our NLSY data set contains the following nine year-age ranges for the six survey years. ${ }^{6}$

Survey Year

$\begin{array}{lcccccc} & 1985 & 1986 & 1987 & 1988 & 1989 & 1990 \\ & 20 & 21 & 22 & 23 & 24 & 25 \\ & 21 & 22 & 23 & 24 & 25 & 26 \\ \text { Respondent } & 22 & 23 & 24 & 25 & 26 & 27 \\ \text { Age } & 23 & 24 & 25 & 26 & 27 & 28 \\ & 24 & 25 & 26 & 27 & 28 & 29 \\ & 25 & 26 & 27 & 28 & 29 & 30 \\ & 26 & 27 & 28 & 29 & 30 & 31 \\ & 27 & 28 & 29 & 30 & 31 & 32 \\ & 28 & 29 & 30 & 31 & 32 & 33\end{array}$

We track wealth accumulation in two ways. First, we follow each household through time (from age 20 to 25 , age 21 to 26 , etc.). The path of real wealth is measured by the mean wealth of an age group.

Second, we compare the age-specific level of real wealth attained in different years. For example, the real wealth of 25 year old youth in 1985 can be compared to that of those age 25 in 1986. This comparison is made along the southwest to northeast diagonals of the above chart, rather than going from left to right. 
We also compare wealth profiles based on

differences in exogenous variables including gender and race/ethnicity (black, Hispanic, white/other).

Further comparisons are based on a set of variables that are subject to choice, but are relatively stable over time. Examples include measures of educational attainment, aptitude, health, family background, and regional geographic location. For variables such as the aptitude test score, we separate the weighted NLSY data into four equal size groups and report the average wealth profile in each. For location, we separate the urban sample into four groups covering the range of constantquality house prices.

The final variables related to wealth accumulation are endogenous choice variables that possibly change by significant amounts over time; examples include marital status, fertility, and labor supply.

\section{RESULTS: NATIONAL SAMPLE}

We present a series of tables and figures that show the accumulation of real wealth and history of renting/homeowning from 1985 to 1990. The national sample contains 4910 respondents and is designed such that truncation or missing data in any year result in deletion of that household in all years.' Thus, variations in means are not a result of respondent attrition or reappearance in the data 
set. Data are weighted to reflect the national youth population. The base year for deflation of nominal variables is 1985.

\section{A. Age and Wealth}

Table 3 presents the age-wealth relationship. Reading across a row indicates the increase in wealth gained by households categorized by the 1985 age of the respondent. We find that real wealth increases rapidly; it takes about four years to triple at ages 20-23 and double at ages 24-28. The mean annual increase is 228, ranging from 8.18 in 1985-86 to 33.38 in 1986-87. This increase in household wealth results from both saving and marriage. ${ }^{8}$

Reading Table 3 southwest to northeast tracks the change in wealth of a particular respondent age across different years. The transcribed data (Table 4) reveal substantial sampling variation, making inferences difficult. However, for ages 22-28, real wealth is greater for respondents of a particular age in the latest year data are available than in 1985 (the exception is age 27). This result suggests that the real wealth-age profile of young households was rising during 1985-90. There also appears to have been a modest decline in the level of age-constant real wealth in 1986, largely due to a decline in real farm prices. ${ }^{9}$ 
B. Other Variables and Wealth

We next report wealth profiles by respondent's gender and race/ethnicity. We further separate the sample by marital status because age-specific marriage rates differ by gender and race/ethnicity.

Figure 1 indicates that the wealth of single female respondents is only 658 of the level of male respondents. In contrast, the wealth of married female respondents is about $7 \%$ greater than married male respondents, presumably because women tend to marry older men who have greater wealth. Figure 2 displays real wealth by race/ethnicity and marital status. Single whites average about three and a half times more wealth than blacks and 508 more than Hispanics throughout the period. Married whites' wealth is nearly three times that of married blacks and is 758 greater than mean Hispanic wealth. ${ }^{10}$

Real wealth levels for two measures of human capital, highest grade completed and score on an aptitude test, are reported in Figures 3 and 4 . The respondent's highest grade completed by 1990 is separated into four categories: less than 12, 12, 13 to 16 , and 17 or more. We highlight the results for 1990 when respondents were ages 25-32; thus, most were out of school and in the labor force. The results show that wealth rises with education. Results for 1985-89 also show that wealth rises with education except that the wealth of more highly educated but young respondents is low compared with 
less educated youth when the highly educated youth are still in school rather than in the labor force.

Figure 4 displays the level of wealth for four quartiles of aptitude test scores. This test measures age adjusted abilities in mathematics and reading. The difference in wealth comparing highest to lowest quartile is dramatic (about 4508).

Table 5 lists wealth for households categorized by one of eight marital histories. The first column is for respondents that remained single throughout 1985-90. The next six columns report wealth for households that first married in the indicated year. ${ }^{11}$ The final column contains households that followed some other marital pattern including divorce, separation, widowhood, and remarriage. We find there is a significant increase in wealth upon marriage, more than doubling in every year except 1986. A large increase is expected because the wealth of two singles is combined. ${ }^{12}$ Increased household wealth relaxes the downpayment constraint to the extent that the desired housing quantity increases proportionately less than does their wealth. 13

Wealth accumulation is influenced by income and thus work hours. To simplify the presentation, we categorize respondents into four groups based on the number of hours worked in 1990. Figure 5 displays the expected positive correlation of 1990 real wealth and respondent's 1990 labor supply. 
Interestingly, this correlation also holds for levels of wealth reported in 1985-89, suggesting that those with greater labor supply in 1990 also had greater supply in earlier years.

\section{Homeownership and Wealth}

Homeownership and real wealth are highly correlated. Table 6 presents the wealth profile of eight groups of households including those who rented continuously during 1985-90, first time owners in each year 1986 to 1990 (five groups), those who owned prior to or became owners in 1985, and others (e.g., those who switched from owning to renting). Three results are notable.

First, significant wealth accumulation occurs during the year of purchase of the house. Household wealth more than doubles for people becoming owners in all years except 1986 ( $50 \%$ increase). One explanation for this result is the previously noted correlation of the year of marriage (hence increase in wealth) with first ownership. ${ }^{14}$ Wealth also accumulates at a significant rate in the year before first ownership ( 33 percent gain on average). Second, wealth accumulation (which includes home equity) occurs at a relatively rapid rate following first ownership, the average annual growth rate being 17 o during the sample period. This result likely reflects the highly leveraged investment in an appreciating asset. 
The final, and possibly most notable, result is that the wealth of nonowners is a good predictor of the timing of their future shift to homeownership. For example, households that became owners in 1990 had lower wealth in 1985 than did households that became owners in 1989. This relationship holds for a11 other combinations of years (wealth increases across rows, comparing Owner-1990 to Owner-1989, ..., to Owner-1985). Moreover, households that became owners in 1990 had greater wealth than did those renting in 1990 for at least the five prior years. Thus, wealth is a leading indicator of the probability of homeownership many years into the future. Generally, current renters have not chosen to save for homeownership. ${ }^{15}$

The wealth-ownership pattern raises the question of how households manage to accumulate assets rapidly just prior to homeownership, besides marriage. One possibility is a significant increase in work effort. Tables 7 and 8 report mean annual work hours using the same categorization of households as in Table 6 . The data in Table 7 indicate that the work effort of married males generally increases during the year prior to and concurrently with first ownership, but the increase is not significantly different from the general upward drift with increasing age. ${ }^{16}$ Thus, increased male work effort appears to contribute only marginally to wealth accumulation just before 
homeownership.

Work effort of married women displays a different pattern (Table 8). Again there is a general upward trend as age increases; however, the increase in hours worked during the year of house purchase is relatively large. While the average annual increase in years other than the year of purchase is 25 hours, during the purchase year it is 222 . This increase is sustained for a few years after the house purchase. The percentage of females whose labor supply increased 400 or more hours is 21 in the year of purchase, compared to a mean of 15 in other years before ownership.

Given the jump in married female hours worked, one might not expect a rise in fertility until a few years after marriage. In fact, fertility rises in the year of first homeownership (Table 9). Per year, about 1 in 16 households that rented from 1985-90 have an additional child. The rate is higher for renters who became owners during 1986-90 (1 in 12). Once homeowners, the rate jumps to 1 in 6 and remains at approximately the same level during the next few years. This behavior suggests the possibility of simultaneous fertility and marriage/homeownership decisions. Simultaneity implies that households delay fertility until marriage and ownership are feasible and that the desire for children increases the tendency to marry and select homeownership rather than rent. 
The increase in work effort near the date of first homeownership should be reflected in rising household income. Table 10 indicates the variation in real total household income for the eight categories of ownership history. Real income rises 9.08 in the year just prior to and in the first year of homeownership compared to an average upward trend in income of 7.38 for owners and 5.48 for renters. ${ }^{17}$

Another possible source of new wealth is gifts (or inheritances). If these funds are a significant factor, then the percentage of new homeowners receiving gifts should be nontrivial and the amount received should be relatively large. Table 11 reports the percentage of households in each homeownership category receiving windfall income of over $\$ 100$ during the period 1988-90 (data on gifts before 1988 are less reliable because the survey question about gifts covers multiple years.) The percentage of households receiving gifts in the year of first homeownership is significantly greater than the percentages of renters or existing owners. ${ }^{18}$ Also, the mean size for those households that received a gift of more than $\$ 100$ in the year of home purchase is $\$ 5,224$. Of those households that received a gift in 1988 and purchased a house, the average value of the gift equaled 198 of the purchase price of their house. The comparable percentages were 138 in 1989 and $15 \%$ in 1990. Over 
$60 \%$ of gifts received during the year of purchase were at least 58 of the value of the house. ${ }^{19}$ Also, more owners continue to receive gifts than do renters, suggesting a pattern of continuing parental support for a few years after first homeownership.

\section{Results: Metropolitan Area Sample}

When we restrict the national sample to respondents residing in the 80 areas for which we have constant-quality house prices, our sample size falls to $1355 .^{20}$ After describing the distribution of constant-quality house prices, we focus on renters because of our interest in analyzing their behaviors prior to homeownership. Relationships between real house prices and renters' wealth, marriage, fertility, labor supply, and household formation are described.

A. Real House Price, Real Wealth, and Homeownership In this sample, average metropolitan area constant-quality real house prices range from $\$ 60,000$ to $\$ 117,536$ in 1985 and $\$ 60,377$ to $\$ 181,278$ in 1990. We divide observations into four approximately equal sized groups, using 1985 real house prices. Cutoff points for the 1985 quartiles are 1isted in the top panel of Table $12 .{ }^{21}$ The lower panel lists the average prices of these constant-quality houses in later years. Populationweighted average real house prices in the 80 
localities grew at a 2.58 annual rate from 1985-90.

The highest house price category grew at a rate four times greater than other categories, with the 1989 jump being particularly remarkable.

Two opposing economic forces affect the desire of renters to become owners and thus the wealthhomeownership relationship. First, there is the we11 known tax advantage of homeownership for higher income (tax bracket) households (Buser and Sanders, 1983; Litzenberger and Sosin, 1978). Renting is optimal for low income households because landlords' tax benefits (reflected in the rent) exceed those that they can obtain as owners. ${ }^{22}$ Thus, to meet the downpayment constraint, high income renters have an incentive to save that low income renters do not have. An opposing force on high income renters is that increased savings causes a greater intertemporal distortion in consumption. If preferences imply consumption should be smoothed over the lifetime, young households with relatively low current income will tend to dissave in the absence of a downpayment constraint. The greater is the cost of the distortion relative to the present value gain in tax benefits, the less rapidly will the household save for ownership.

Variations in constant-quality real house prices affect the forces that determine the time to first homeownership. ${ }^{23}$ The greater the amount of real wealth required for a downpayment, the greater the 
intertemporal distortion. Thus, households living in high real house price areas will be more likely to rent longer. But, the tax benefit of homeownership is larger for itemizing high income renters in high constant-quality house price areas, ceteris paribus. The empirical implication is that the desire to own by middle and upper (permanent) income renting youth may rise or fall the higher is the constant-quality house price. For low income renters whose tax advantage of becoming a homeowner is small, we expect to find little variation in wealth with constant-quality house prices.

The relationship between renters' real wealth and real constant-quality house prices is displayed in Figure 6 . The data show that a positive relation between wealth and constant-quality house price exists through the 75 th percentile; thereafter, the relationship turns negative. This pattern is most evident in 1990 when respondents were age 25-32.

Next, we investigate whether the relationship between wealth and constant-quality house price holds for only middle and upper income or all young renting households. Rather than separating renters by current income levels, we use the respondent's aptitude test score because it is correlated with permanent income, a better indicator of the expected tax advantage of owning. Table 13 reports wealth for renters in the top, middle, and bottom third of the distribution of test scores. For high and 
middle levels of aptitude score, we find a pattern generally similar to that in Figure 6; wealth levels initially rise with constant-quality house prices, but then fall in the highest price localities. For households with low test scores, thus presumably low permanent income and little incentive to own, wealth varies little with constant-quality house price.

Homeownership rates for the metro area sample are shown in Figure 7. Rates decline slightly in the first three quartiles and are sharply lower in the highest real house price areas in all years. ${ }^{24}$ The means for the period $1985-90$ are $0.21,0.21,0.19$, and 0.10 .

B. Real House Prices and the Behavior of Renters The next series of figures reports on choices made by renters residing in localities that differ in real constant-quality house price. We discuss the marriage and fertility rates, labor supply, and income. Figure 8 shows the marriage rate of renters. We observe the expected upward trend over time as the cohort ages, and note a modest negative correlation of the marriage rate with the real constant-quality house price. In areas with constant-quality house prices in the top half of the distribution, the marriage rate is about five percentage points lower than in areas in the bottom half. We find no relationship between renters' fertility rate and the constant-quality house price 
$(\rho=0.02)$.

Our analysis of variations in labor supply with constant-quality house price includes only respondents with aptitude test scores in the highest two-thirds of the distribution. The quantity of renting male respondents' work hours varies little across the four house price quartiles. However, female respondents' work hours rise with house price up to the 75 th percentile, but are lower in the highest cost areas for both the middle third and top third of aptitude test scores. The mean values for the 1985-90 period are: $1814,1843,1851,1726 .{ }^{25}$

Compared to youth in low real constant-quality house price areas, those in high house price localities who wish to achieve ownership are likely to reduce their consumption, which suggests a reduction in the quantity of rented housing. If the real rental cost is also higher, youth in areas with both high real house prices and rents should opt for a significant reduction in the quantity of rental housing consumed. ${ }^{26}$ Possible behaviors that would reduce rental consumption include living in groups rather than alone or living with parents (Haurin, Hendershott, and Kim, 1993, 1994).

Figure 9 shows mean constant-quality rental prices in the four quartiles of house price, and we find the expected strong positive linkage of mean real constant-quality house prices and rental rates $(\rho=0.90)$. We again limit the sample to respondents 
with aptitude test scores in the highest two-thirds of the distribution. We find that the rate youth living with parents is not related to constantquality house price; however, the rate that they live in groups rises substantially with increased house price. The 1985-90 means for the four house price quartiles are: $0.14,0.18,0.21,0.22 .{ }^{27}$

\section{v. SUMMARY OF THE ANALYSIS}

Using a national sample, we have found that the real wealth of young adults is positively correlated with age, race/ethnicity (whites highest, then Hispanic, then blacks), good health, gender (males higher if single), labor supply, and ability as measured by an aptitude test score and highest grade completed.

The first question of economic interest is how youth, who typically leave parents with relatively little wealth, accumulate funds for a downpayment. We have found that wealth increases significantly in the two years before first homeownership. This finding is consistent with Mayer and Engelhardt (1994) who report that first time home buyers took 2.3 years to save for the downpayment. High rates of marriage just before and during the year of first homeownership are part of the explanation of the rapid accumulation of wealth. Another source is gifts and inheritances. During the year of home purchase, about 148 of youth receive gifts of over 
$\$ 100$, triple the rate of years prior to ownership.

Over $60 \%$ of gifts during the year of purchase exceed 58 of house purchase price. A third factor is that the labor supply of married females rises substantially during the year of first ownership and remains high for at least a few years afterwards. of all married women, the number of hours worked in

the year of home purchase increases by 400 or more for 218 .

The second finding of interest is that household wealth is a leading indicator of homeownership. Greater wealth up to five years prior to purchase is positively correlated with the eventual probability of becoming a homeowner.

The third finding is that real constant-quality house prices in a locality are nonlinearly related to the wealth of high permanent income renters. A small positive correlation is observed across low and mid-priced areas; however, the correlation becomes negative in communities with high house prices. This observation corresponds to the conjecture that because the downpayment constraint is difficult to overcome in areas with very high real house prices, young households choose not to save and pursue ownership ("consumption of despair," Sheiner, 1995).

Other variables are also related to constantquality house prices. We find that the 
homeownership rate declines slightly with increases in the real constant-quality house price in areas with low and mid house prices, and is substantially lower in high price localities. The marriage rate is negatively correlated with house prices, but the fertility rate is uncorrelated. Female renters' labor supply is positively related to real house prices over most of the price range, but declines in the higher priced areas (perhaps "leisure of despair"). Real constant-quality house prices and rental rates are positively correlated in our sample. Renters who face high real dwelling costs must substitute away from housing to reduce consumption and save. We find that one form of this substitution is that youth residing in high constant-quality house price areas live in groups at a significantly greater rate. 
1. Wealth data from older cohorts of the NLS have been used in studies of wealth accumulation (Jianakoplos, N., P. Menchik, and F. Irvine, 1989). The survey questions on wealth in the NLS and NLSY are basically identical.

2. A review of the untruncated data reveals that sample means can be strongly influenced by a few very large wealth values when the sample size is as smal1 as in the SCF. Thus, comparison of the averages of the two truncated distributions is meaningful.

3. The localities are:

Northeast: Baltimore, Buffalo, Hartford, Syracuse, Harrisburg, Binghamton, Lancaster, Wilmington, Erie, Philadelphia.

Southeast: Atlanta, Miami, Memphis, Norfolk, Louisville, Birmingham, Nashville, West Palm Beach, Charlotte, Chattanooga, Mobile, Knoxville, Augusta, Greenville, Columbus GA, Montgomery, Lexington, Roanoke, Winston-Salem, Greensboro, Raleigh, Columbia, Richmond.

North Central: St. Louis, Cincinnati, Kansas City, Indianapolis, Columbus $\mathrm{OH}$, Akron, Omaha, Youngstown, Peoria, Canton, Fort Wayne, South Bend, Rockford, Lincoln, Quad-cities, Cleveland.

Southwest: Houston, Denver, New Orleans, San Antonio, Oklahoma City, Salt Lake City, El Paso, Tulsa, Albuquerque, Baton Rouge, Wichita, Colorado Springs, Lubbock, Provo, Da11as, Austin.

West: San Diego, Phoenix, San Jose, Portland, Sacramento, Riverside, Las Vegas, Tacoma, Fresno, Reno, Anchorage, Tucson, Los Angeles, Seattle, Spokane.

Further details about the steps used in developing the 
house price and rental series are in Kim (1993).

4. We compared the 1985-90 American Chamber of Commerce house price data ( 80 areas) to the Freddie Mac/Fannie Mae (FF) repeat sales house price index for 123 areas. There are 54 localities common to both data sets. The FF series reports nominal house price indexes for each area using 1987 as the base year for each series. We normed the cross-sectional price variation using the 1987 ACC house price data, thus the two series are identical in 1987. We deflated the FF series using the CPI-U all item index.

The correlation of the series for the 1985-90 period is 0.89 . The sample mean prices (unweighted) in each year are (ACC:FF): 1985 (80186:77178), 1986 (82446:81268), 1987 (82629:82629), 1988 (83611:85081), 1989 (86406:86509), 1990 (86255:85066). The FF series has a standard deviation 118 greater than the ACC index. Also, the average annual rate of increase in real house price is 0.5 percentage points higher in the FF series.

5. The number of local area CPIs is limited, thus using state data allows all observations to remain in the sample. The population weighted mean price index is: $1985=100,1986=102.5,1987=105.4,1988=108.6$, $1989=112.0$, and $1990=113.9$.

6. The respondents were age $14-21$ in 1979 , thus should be 20-27 in 1985. Because of variations in survey date, some respondents had turned 28 . The sample size of those 28 is considerably smaller than for the other ages.

7. The NLSY sample surveyed 12,686 respondents in 1979. A military sample of 1,079 was dropped in 1985. In $1990,10,259$ respondents were surveyed. Nonresponse to the questions relevant to our study and elimination of truncated wealth observations reduces the 1985-90 sample to about 5600. Further elimination of respondents that did not answer the wealth questions every year reduces the sample to 4910 . 
8. Reading down a column yields a cross-sectional snapshot of wealth for households age 20-28 in 1985, 21-29 in 1986, etc.

9. Review of data in this and a number of the following tables indicates that the increase in wealth from early 1985 to early 1986 is less than the long term upward trend. Survey questions about wealth in 1985, 1986, and 1987 are identical. Further analysis indicates that the wealth category largely responsible for this effect is the "Value of Farm and Business". The real value of farms declined by 11.88 in 1985 , another 6.98 in 1986, and then were about constant through 1990 (Statistical Abstract, 1993). The large decline in farm values in 1985 is consistent with our data (a $\$ 580$ decline occurs in the Farm/Business category from 1985 to 1986 ).

10. Wealth levels are also related to the respondent's health. The difference in wealth between respondents reporting a health impairment that limits the type or amount of work is about 308 in 1985, rising to $130 \%$ in 1990. (In 1990, $93 \%$ of the respondents are categorized as having good health.)

11. The NLSY allows single respondents to indicate whether they live with a "partner" of the opposite gender. We categorize respondents with partners as single.

12. Also, the wealth of each individual in the couple grows during the year-long period.

13. The increase in the homeownership rate is from 0.11 in the year prior to marriage to 0.35 in the marriage year. Two years prior to marriage, the homeownership rate is 0.08 and the rate for those youth married for two years is 0.48 .

14. If a respondent marries a homeowning individual, we classify the event as an incident of first homeownership. However, relatively few unmarried 
youth are homeowners.

15. Alternatively, the higher the desire for ownership, the greater is wealth.

16. We focus on married respondents because relatively few singles are owners in our sample.

17. The increase in the mean real wage rate is $\$ 0.91$ during the year of first homeownership compared to $\$ 0.81$ in prior years (beginning in 1985).

18. The survey questions are designed such that parental loans would be included in housing debt, not gifts. A respondent could use a parental loan as part of the downpayment and would report the total house debt as the sum of mortgage and parental loans. (The survey question on house debt also includes back taxes, home improvement loans and bills, and assessments.) The result would be a high house debtto-value ratio. The average ratio in the first year of homeownership is 0.71 . However, 188 of new owners report house debt-to-value ratios of greater than 0.95 . Also, 118 of new owners report ratios of 1.0 or more (68 equal exactly 1.0). These data suggest that some young new homeowners receive loans from parents.

19. Mayer and Engelhardt (1994) also find gifts to be an important source of funds for first time homeowners. Using 1983 and 1985 Survey of Consumer Finance data for households of all ages, Gale and Scholz (1994) find that 15.68 of recipients of gifts of $\$ 3,000$ or more were first time home buyers during 1983-85.

20. The 80 MSAs contained 408 of the total U.S. population in 1990, while the corresponding central cities contained 128 of the population. In the NLSY, the basic geographic unit is the county, thus our spatial coverage lies between MSAs and central cities, and the coverage of the youth population lies between the above two percentages. 
21. The match of localities to the four constantquality house price quartiles in 1985 is:

Lowest 25\%: Peoria, Buffalo, Knoxville, Erie, Montgomery, Syracuse, Lancaster, Louisville, Wichita, Houston, Akron, Chattanooga, Mobile, Harrisburg, Kansas City, South Bend, Provo, Oklahoma City, Philadelphia, Cleveland

25\%-50\%: Lubbock, Fort Wayne, Birmingham, Omaha, Portland, Rockford, Cincinnati, Seattle, West Palm Beach, Quad-Cities, Columbus, Spokane, Salt Lake City, E1 Paso, Miami, Richmond, Fresno, Indianapolis, St. Louis, Columbia

50\%-75\%: Binghamton, Greenville, New Orleans, Norfolk/Va. Beach, Baton Rouge, Tulsa, Colorado Springs, Canton, Columbus IN, Nashville, Dallas, Memphis, San Antonio, Baltimore, Tucson, Youngstown, Tacoma, Augusta, Lincoln, Las Vegas

Highest 258: Lexington, Charlotte, Winston-Salem, Phoenix, Hartford, Albuquerque, Sacremento, Atlanta, Reno, Greensboro, Roanoke, Austin, Wilmington, Riverside, Raleigh, Los Angeles, Anchorage, Denver, San Jose, San Diego

22. For some households, renting may be optimal throughout their lifetime.

23. For households that are inframarginal renters, these variations have no impact.

24. The correlation of the homeownership rate and the mean constant-quality house price $(24$ cells) is -0.48 . Recall that the mean real house price is significantly larger in the fourth quartile.

25. The relationship between renter's real total household income and constant-quality house prices is similar. In the highest house price localities, income averages about $5 \%$ less than in the other three regions. 
26. Unfortunately, the NLSY data set does not report expenditures on rental units.

27. Many youth move from parental household to homeowning spending little, if any, time renting. The percentage of new homeowners who lived with parents in the previous year are: $1985-17,1986=17,1987=21$, 1988-1990=13. 


\section{REFERENCES}

ACCRA: American Chamber of Commerce Researchers Association, "Cost of Living Index Manual", 1988.

Armstrong, T., A. Chalupsky, D. McLaughlin, and M. Dalldorf, "Armed Services Vocational Aptitude Battery: Validation for Civilian Occupations", Working paper, Air Force Human Resources Laboratory, 1988.

Bilsborrow, R. and J. Akin, "Data Availability versus Data Needs for Analyzing the Determinants and Consequences of Internal Migration: An Evaluation of U.S. Survey Data", Review of Public Data Use, Vol. 10, No. 4, Dec. 1982, 261-284.

Blau, F. and J. Graham, "Black-White Differences in Wealth and Asset Composition", Quarterly Journal of Economics, Vol. 105, No. 2, May 1990, 321-339.

Buser, S. and A. Sanders, "Tenure Decisions Under a Progressive Tax Structure", Journal of the American Real Estate and Urban Economics Association, Vol. 11, Fal1 1983, 371-381.

Center for Human Resource Research, NLS Handbook, Ohio State University, 1993.

Cherlin, A. and S. Horiuchi, "Retrospective Reports of Family Structure: Methodological Assessment", Sociological Methods and Research, Vol. 8, May 1980 , 454-469.

Engelhardt, G., "House Prices and the Decision to Save for Down Payments", Journal of Urban Economics, Vol. 36, No. 2, Sept. 1994, 209-237.

Gale, W., and J. Scholz, "Intergenerational Transfers and the Accumulation of Wealth", Journal of Economic Perspectives, Vol 8, No. 4, Fall 1994, $145-160$. 
TABLE 1: Mean Values of Socio-Demographic Variables in the SCF and NLSY: Respondents Age 24-31

\begin{tabular}{|l|c|c|}
\hline Variable & SCF & NLSY \\
\hline Age of Head & 28.4 & 28.8 \\
\hline Mumber of Children & 1.13 & 1.01 \\
\hline t Male Head & 14.0 & 18.6 \\
\hline Married & 56.3 & 52.8 \\
\hline Divorced, Widowed, Separated & 12.3 & 13.9 \\
\hline Homeowner & 39.3 & 34.3 \\
\hline White & 75.8 & 73.9 \\
\hline
\end{tabular}


TABLB 2: Mean Wealth in the SCE and NLSY; Respondents Age 24-31

\begin{tabular}{|l|r|r|}
\hline Variables & \multicolumn{1}{|l|}{ SCE } & \multicolumn{1}{l|}{ NLSY } \\
\hline Homeowners' Bquity & 15,330 & 16,155 \\
\hline Liquid Wealth & 5,263 & 3,399 \\
\hline Mutual and Investment Funds & 2,352 & 1,293 \\
\hline Value of Durables & 681 & 1,404 \\
\hline Value of Farm and Busineas & 4,499 & 2,904 \\
\hline Wealth & 28,125 & 25,155 \\
\hline Gifts & 238 & 272 \\
\hline
\end{tabular}


TABLE 3: Real Household Wealth by Respondent's Age, Longitudinal Profile: 1985-90.

\begin{tabular}{|l|c|c|c|c|c|c|c|}
\hline \multirow{2}{*}{$\begin{array}{l}\text { Age } \\
\text { in } \\
1985\end{array}$} & \multicolumn{8}{|c|}{ Real Wealth } \\
\cline { 2 - 8 } & 1985 & 1986 & 1987 & 1988 & 1989 & 1990 & Sample size \\
\hline 20 & 3410 & 3198 & 5332 & 8519 & 10005 & 12224 & 525 \\
\hline 21 & 4136 & 4992 & 7082 & 8917 & 10065 & 15672 & 774 \\
\hline 22 & 4586 & 5332 & 8339 & 10654 & 13258 & 16213 & 741 \\
\hline 23 & 6262 & 7784 & 12937 & 15852 & 17018 & 19304 & 721 \\
\hline 24 & 8875 & 8915 & 11849 & 13428 & 15670 & 19440 & 670 \\
\hline 25 & 9607 & 10220 & 14977 & 16114 & 20847 & 24118 & 605 \\
\hline 26 & 12032 & 12472 & 16714 & 22251 & 23051 & 24134 & 555 \\
\hline 27 & 17072 & 16764 & 22297 & 24435 & 28273 & 32759 & 544 \\
\hline 28 & 17673 & 20744 & 21016 & 24811 & 31852 & 38798 & 119 \\
\hline Mean & 9295 & 10047 & 13394 & 16109 & 18893 & 20358 & \\
\hline
\end{tabular}


31

TABLB 4: Inter-Cohort Age-Constant Comparison of Real Household Wealth: 1985-90.

\begin{tabular}{|c|c|c|c|c|c|c|}
\hline \multirow{2}{*}{$\begin{array}{c}\text { Constant } \\
\text { Age }\end{array}$} & \multicolumn{6}{|c|}{ Real Nealth } \\
\cline { 2 - 8 } & 1985 & 1986 & 1987 & 1988 & 1989 & 1990 \\
\hline 22 & 4586 & 4992 & 5332 & $\ldots$ & $\ldots-$ & $\ldots$ \\
\hline 23 & 6262 & 5332 & 7082 & 8519 & $\ldots-$ & $\ldots$ \\
\hline 24 & 8875 & 7784 & 8339 & 8917 & 10005 & $\ldots-$ \\
\hline 25 & 9607 & 8915 & 12937 & 10654 & 10065 & 12224 \\
\hline 26 & 12032 & 10220 & 11849 & 15852 & 13258 & 15672 \\
\hline 27 & 17072 & 12472 & 14977 & 13428 & 17018 & 16213 \\
\hline 28 & 17673 & 16764 & 16714 & 16114 & 15670 & 19304 \\
\hline
\end{tabular}


TABLE 5: Mean Real Household Wealth by zight Categories of Marital History: $1985-1990$.

\begin{tabular}{|c|c|c|c|c|c|c|c|c|}
\hline \multirow{2}{*}{ Year } & \multicolumn{9}{|c|}{ Real Wealth } \\
\cline { 2 - 10 } & Single & $\begin{array}{c}\text { Married } \\
1990\end{array}$ & $\begin{array}{c}\text { Married } \\
1989\end{array}$ & $\begin{array}{c}\text { Married } \\
1988\end{array}$ & $\begin{array}{c}\text { Married } \\
1987\end{array}$ & $\begin{array}{c}\text { Married } \\
1986\end{array}$ & $\begin{array}{c}\text { Married } \\
1985\end{array}$ & Other \\
\hline 1985 & 3987 & 3955 & 4844 & 6050 & 6898 & 9664 & 16308 & 9898 \\
\hline 1986 & 4127 & 5522 & 4644 & 7077 & 7582 & 12931 & 17486 & 9422 \\
\hline 1987 & 6108 & 10448 & 4926 & 9850 & 20385 & 19079 & 22624 & 11892 \\
\hline 1988 & 7471 & 10163 & 7352 & 21789 & 19832 & 21961 & 26567 & 13262 \\
\hline 1989 & 8371 & 10595 & 19648 & 26705 & 28619 & 25602 & 30246 & 13050 \\
\hline 1990 & 9916 & 26799 & 19028 & 35836 & 30355 & 37016 & 34921 & 10166 \\
\hline
\end{tabular}


TABLE 6: Mean Real Household Wealth by Eight Categories of Ownership History: 1985-1990.

\begin{tabular}{|c|c|c|c|c|c|c|c|c|}
\hline \multirow{2}{*}{ Year } & \multicolumn{8}{|c|}{ Real Wealth } \\
\cline { 2 - 10 } & $\begin{array}{l}\text { Renter } \\
1985-90\end{array}$ & $\begin{array}{r}\text { Owner } \\
1990\end{array}$ & $\begin{array}{r}\text { Owner } \\
1989\end{array}$ & $\begin{array}{r}\text { Owner } \\
1988\end{array}$ & $\begin{array}{r}\text { Owner } \\
1987\end{array}$ & $\begin{array}{r}\text { Owner } \\
1986\end{array}$ & $\begin{array}{r}\text { Owner } \\
1985\end{array}$ & Other \\
\hline 1985 & 3326 & 4121 & 5578 & 6742 & 10290 & 12714 & 29615 & 14834 \\
\hline 1986 & 3082 & 4389 & 4911 & 8465 & 12103 & 18721 & 31193 & 16157 \\
\hline 1987 & 4607 & 6387 & 9514 & 11412 & 28785 & 30853 & 39112 & 19070 \\
\hline 1988 & 5510 & 8635 & 12900 & 28513 & 30596 & 35761 & 43354 & 20241 \\
\hline 1989 & 6531 & 12563 & 26442 & 35420 & 36411 & 40804 & 46423 & 20976 \\
\hline 1990 & 8297 & 26183 & 29554 & 46158 & 37615 & 46507 & 54021 & 19401 \\
\hline Mean & 5226 & 10380 & 14817 & 22785 & 25967 & 30893 & 40620 & 18447 \\
\hline
\end{tabular}


TABLE 7: Mean Married Male Hours Worked by Bight Categories of Ownership History: 1985-1990.

\begin{tabular}{|c|c|c|c|c|c|c|c|c|}
\hline \multirow{2}{*}{ Year } & \multicolumn{9}{|c|}{ Hours } & $\begin{array}{l}\text { Renter } \\
1985-90\end{array}$ & $\begin{array}{r}\text { Owmer } \\
1990\end{array}$ & $\begin{array}{c}\text { Owner } \\
1989\end{array}$ & $\begin{array}{c}\text { Owner } \\
1988\end{array}$ & $\begin{array}{c}\text { Owmer } \\
1987\end{array}$ & $\begin{array}{c}\text { Owner } \\
1986\end{array}$ & $\begin{array}{c}\text { Owmer } \\
1985\end{array}$ & Other \\
\hline 1985 & 1680 & 1899 & 1869 & 2125 & 2206 & 2099 & 2175 & 2019 \\
\hline 1986 & 1783 & 1945 & 2218 & 2151 & 2288 & 2282 & 2188 & 2079 \\
\hline 1987 & 1899 & 1957 & 2252 & 2066 & 2176 & 2178 & 2231 & 2179 \\
\hline 1988 & 1979 & 1937 & 2291 & 2193 & 2370 & 2321 & 2290 & 2247 \\
\hline 1989 & 2111 & 2014 & 2304 & 2263 & 2412 & 2320 & 2251 & 2304 \\
\hline 1990 & 2125 & 2111 & 2334 & 2258 & 2412 & 2357 & 2206 & 2392 \\
\hline Mean & 1930 & 1977 & 2211 & 2176 & 2311 & 2260 & 2224 & 2203 \\
\hline
\end{tabular}


TABLE 8: Mean Married Female Hours Worked by Eight Categories of Ownership History: 1985-1990.

\begin{tabular}{|c|c|c|c|c|c|c|c|c|}
\hline \multirow{2}{*}{ Year } & \multicolumn{7}{|c|}{ Hours } & Worked \\
\cline { 2 - 11 } & $\begin{array}{c}\text { Renter } \\
1985-90\end{array}$ & $\begin{array}{r}\text { Owner } \\
1990\end{array}$ & $\begin{array}{r}\text { Owner } \\
1989\end{array}$ & $\begin{array}{r}\text { Owner } \\
1988\end{array}$ & $\begin{array}{r}\text { Owner } \\
1987\end{array}$ & $\begin{array}{r}\text { Owner } \\
1986\end{array}$ & $\begin{array}{r}\text { Owner } \\
1985\end{array}$ & Other \\
\hline 1985 & 995 & 1059 & 1051 & 1349 & 1491 & 1378 & 1343 & 1087 \\
\hline 1986 & 1007 & 1001 & 1229 & 1343 & 1451 & 1628 & 1306 & 1148 \\
\hline 1987 & 1132 & 1324 & 1304 & 1332 & 1678 & 1685 & 1289 & 1236 \\
\hline 1988 & 1277 & 1492 & 1354 & 1607 & 1667 & 1827 & 1307 & 1273 \\
\hline 1989 & 1279 & 1395 & 1547 & 1666 & 1584 & 1677 & 1271 & 1263 \\
\hline 1990 & 1379 & 1559 & 1618 & 1660 & 1473 & 1499 & 1326 & 1240 \\
\hline Mean & 1178 & 1305 & 1351 & 1493 & 1557 & 1616 & 1307 & 1208 \\
\hline
\end{tabular}


TABLE 9: Mean Fertility by Bight Categories of Ownership Hiatory: 1985-1990.

\begin{tabular}{|c|c|c|c|c|c|c|c|c|}
\hline \multirow{2}{*}{ Year } & \multicolumn{6}{|c|}{ Mean Increase in the Number of Children } \\
\cline { 2 - 11 } & $\begin{array}{c}\text { Renter } \\
1985-90\end{array}$ & $\begin{array}{r}\text { Owner } \\
1990\end{array}$ & $\begin{array}{r}\text { Owner } \\
1989\end{array}$ & $\begin{array}{c}\text { Owner } \\
1988\end{array}$ & $\begin{array}{c}\text { Owner } \\
1987\end{array}$ & $\begin{array}{c}\text { Owner } \\
1986\end{array}$ & $\begin{array}{r}\text { Owner } \\
1985\end{array}$ & Other \\
\hline 1986 & 0.07 & 0.05 & 0.06 & 0.08 & 0.10 & 0.14 & 0.19 & 0.09 \\
\hline 1987 & 0.06 & 0.07 & 0.07 & 0.08 & 0.18 & 0.15 & 0.20 & 0.11 \\
\hline 1988 & 0.07 & 0.08 & 0.15 & 0.15 & 0.27 & 0.29 & 0.19 & 0.12 \\
\hline 1989 & 0.05 & 0.07 & 0.13 & 0.13 & 0.16 & 0.09 & 0.15 & 0.05 \\
\hline 1990 & 0.06 & 0.16 & 0.13 & 0.15 & 0.17 & 0.18 & 0.10 & 0.06 \\
\hline Mean & 0.06 & 0.09 & 0.11 & 0.12 & 0.18 & 0.17 & 0.17 & 0.09 \\
\hline
\end{tabular}


TABLE 10: Mean Household Real Income by Eight Categories of Ownership History: $1985-1990$.

\begin{tabular}{|c|c|c|c|c|c|c|c|c|c|}
\hline \multirow{2}{*}{ Year } & \multicolumn{7}{|c|}{ Real Hougehold Income } \\
\cline { 2 - 12 } & $\begin{array}{l}\text { Renter } \\
1985-90\end{array}$ & $\begin{array}{r}\text { Owmer } \\
1990\end{array}$ & $\begin{array}{r}\text { Owner } \\
1989\end{array}$ & $\begin{array}{r}\text { Owner } \\
1988\end{array}$ & $\begin{array}{r}\text { Owner } \\
1987\end{array}$ & $\begin{array}{r}\text { Owner } \\
1986\end{array}$ & $\begin{array}{r}\text { Owner } \\
1985\end{array}$ & Other \\
\hline 1985 & 20754 & 21534 & 20262 & 22821 & 26179 & 32291 & 29710 & 27433 \\
\hline 1986 & 21500 & 24344 & 24089 & 24620 & 30447 & 33046 & 31634 & 28383 \\
\hline 1987 & 22937 & 26095 & 24548 & 27567 & 31900 & 36000 & 34363 & 30372 \\
\hline 1988 & 23606 & 24323 & 28782 & 31210 & 34888 & 38053 & 34998 & 31062 \\
\hline 1989 & 25054 & 26841 & 31032 & 35035 & 33540 & 40860 & 36498 & 31203 \\
\hline 1990 & 27060 & 31822 & 33456 & 36861 & 35790 & 42412 & 37540 & 33659 \\
\hline Mean & 23485 & 25827 & 27028 & 29686 & 32124 & 37110 & 34124 & 30352 \\
\hline
\end{tabular}


TABLE 11: Percentage of Households Receiving Gifts or Inheritances by Eight Categories of Ownership History: 1988-90.

\begin{tabular}{|c|c|r|r|r|r|r|r|r|}
\hline \multirow{2}{*}{ Year } & \multicolumn{6}{|c|}{ Percentage of Householda Receiving O1fts $>\$ 100$} \\
\cline { 2 - 11 } & $\begin{array}{l}\text { Renter } \\
1985-90\end{array}$ & $\begin{array}{r}\text { Owner } \\
1990\end{array}$ & $\begin{array}{r}\text { Owner } \\
1989\end{array}$ & $\begin{array}{r}\text { Owmer } \\
1988\end{array}$ & $\begin{array}{r}\text { Owner } \\
1987\end{array}$ & $\begin{array}{r}\text { Owner } \\
1986\end{array}$ & $\begin{array}{r}\text { Owner } \\
1985\end{array}$ & Other \\
\hline 1988 & 5.0 & 8.0 & 9.4 & 14.3 & 7.3 & 7.6 & 7.0 & 7.7 \\
\hline 1989 & 6.5 & 8.0 & 14.9 & 9.8 & 7.9 & 9.0 & 9.9 & 6.5 \\
\hline 1990 & 5.7 & 13.5 & 10.9 & 9.4 & 6.7 & 4.9 & 7.5 & 5.6 \\
\hline
\end{tabular}


TABLE 12: Range of Constant-Quality Real House Priceg--Quartiles: 1985-1990.

\begin{tabular}{|l|c|c|c|c|c|c|}
\hline & \multicolumn{5}{|c|}{ Real House Price } \\
\hline Year & Minimum & $25 t$ & $50 t$ & $75 t$ & Maximum & Mean \\
\hline 1985 & 60000 & 72367 & 78360 & 88110 & 117536 & 83078 \\
\hline \multicolumn{7}{|c|}{} \\
\hline Quartile Mean of the Constant-Quality Real House Price \\
\hline Year & Iowest 25t & $258-50 t$ & $508-75 t$ & Highest 25t \\
\hline 1985 & 68592 & 75191 & 83003 & 103433 \\
\hline 1986 & 70042 & 78470 & 84410 & 105520 \\
\hline 1987 & 71234 & 78762 & 84428 & 110197 \\
\hline 1988 & 72789 & 80017 & 87193 & 125280 \\
\hline 1989 & 77845 & 81188 & 89598 & 135010 \\
\hline 1990 & 73573 & 81023 & 85075 & 136984 \\
\hline
\end{tabular}


TABLE 13: Renters' Mean Real Wealth by Three Levels of Aptitude Test Score and Four Categories of Real Constant-Quality House Price: 1985 Distribution of House Prices

\begin{tabular}{|l|c|c|c|c|}
\hline \multirow{2}{*}{} & \multicolumn{4}{|c|}{ Renters' Real Wealth for Three Levels of Aptitude } \\
& \multicolumn{4}{|c|}{ Test Score } \\
\cline { 2 - 5 } & 1985 Constant-Quality House Price Quart1les \\
\hline Year & Lowest 25t & $\begin{array}{c}25 t- \\
507\end{array}$ & $507-75 t$ & Highest 25t \\
\hline Mean-top third & 8786 & 11726 & 11582 & 7535 \\
\hline Mean-middle third & 5959 & 5504 & 10809 & 6855 \\
\hline Bottom third & 3095 & 3054 & 3649 & 3232 \\
\hline All Renters & 5827 & 6347 & 8461 & 5718 \\
\hline
\end{tabular}


Figure 1: Mean Real Household Wealth by Respondent's Gender and Marital Status: 1985-90

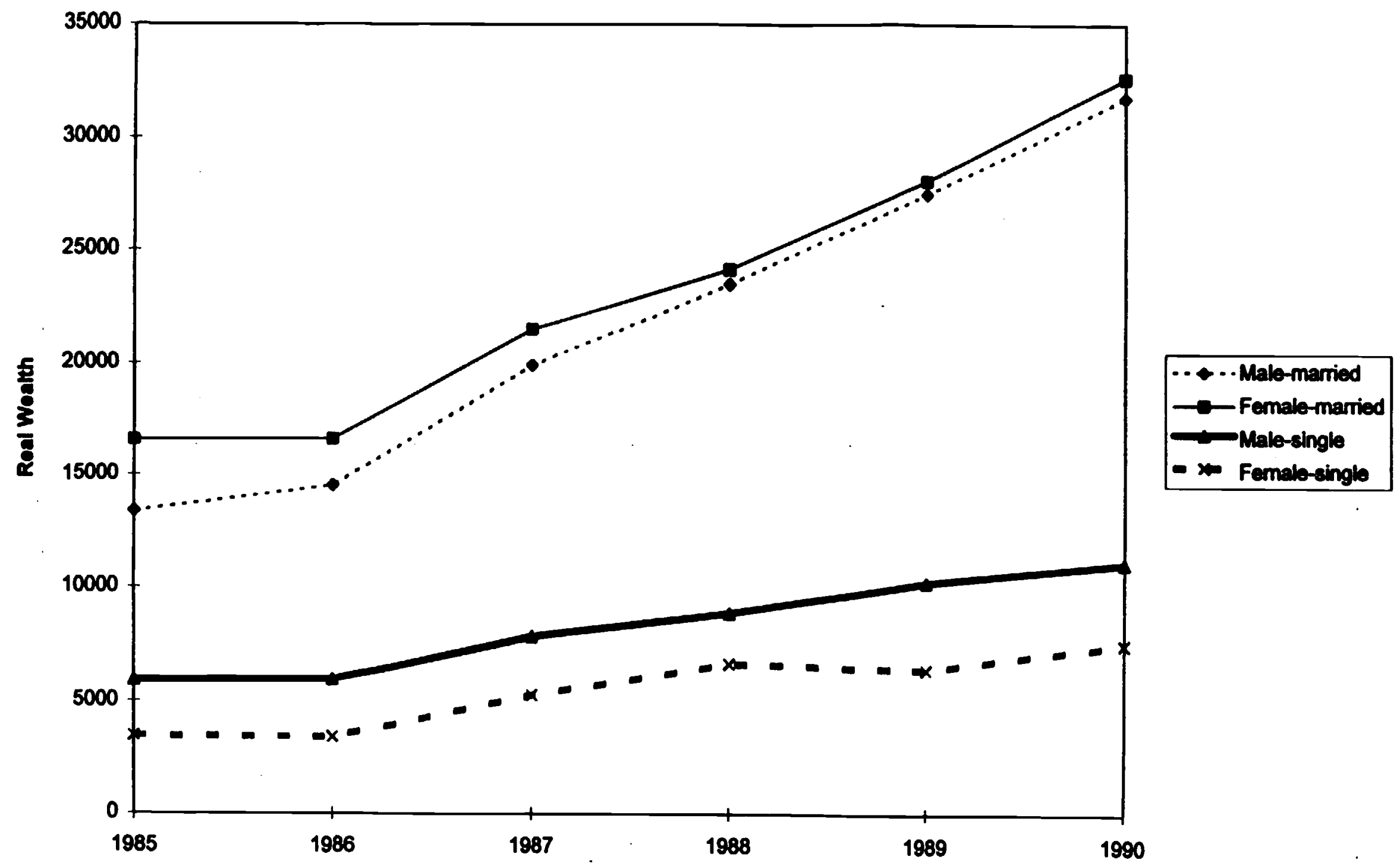


Figure 2: Mean Real Household Wealth by Respondent's Race/Ethnicity: 1985-90

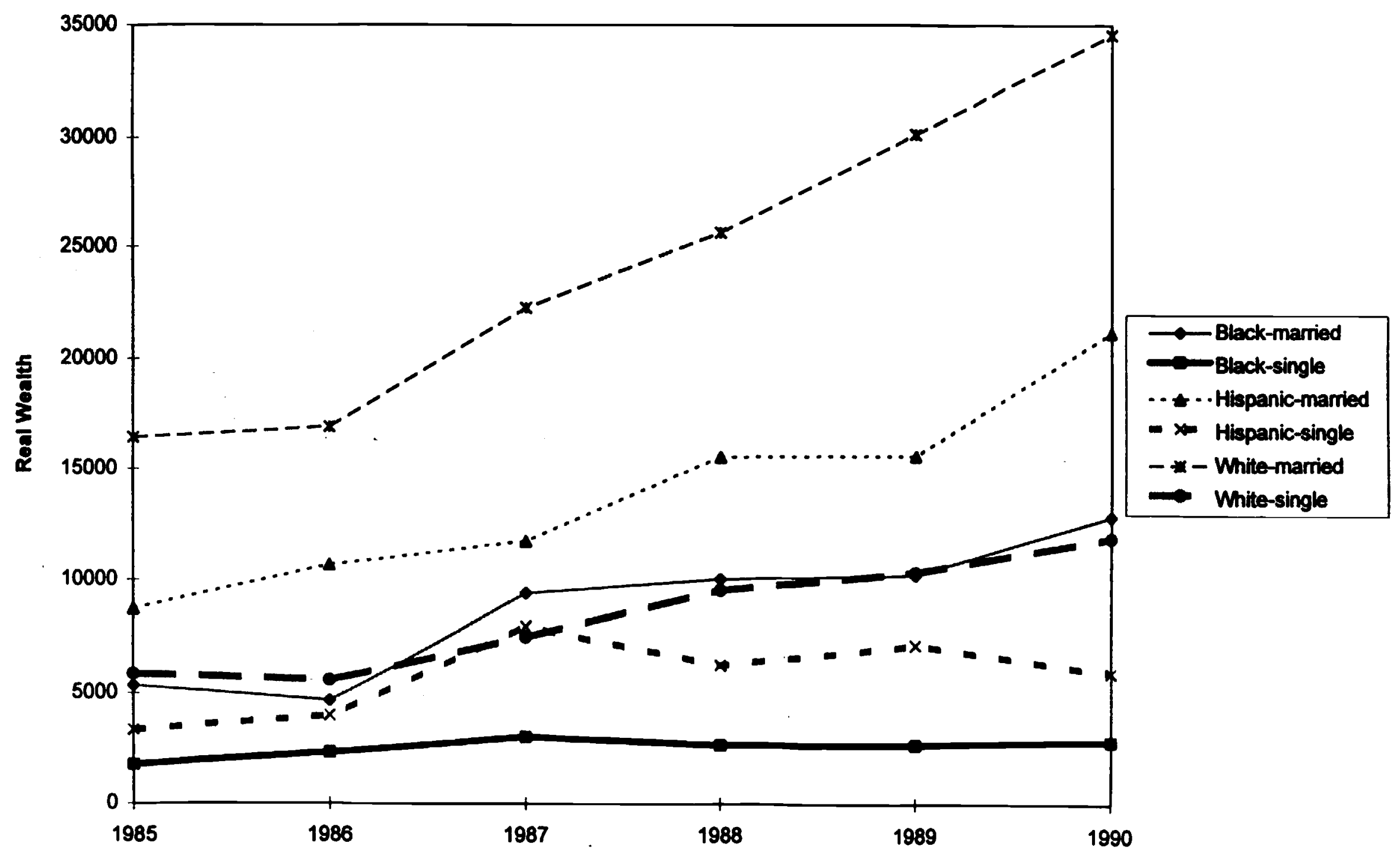


Figure 3: Mean Real Household Wealth by Four Categories of Highest Grade Completed: 1985-90

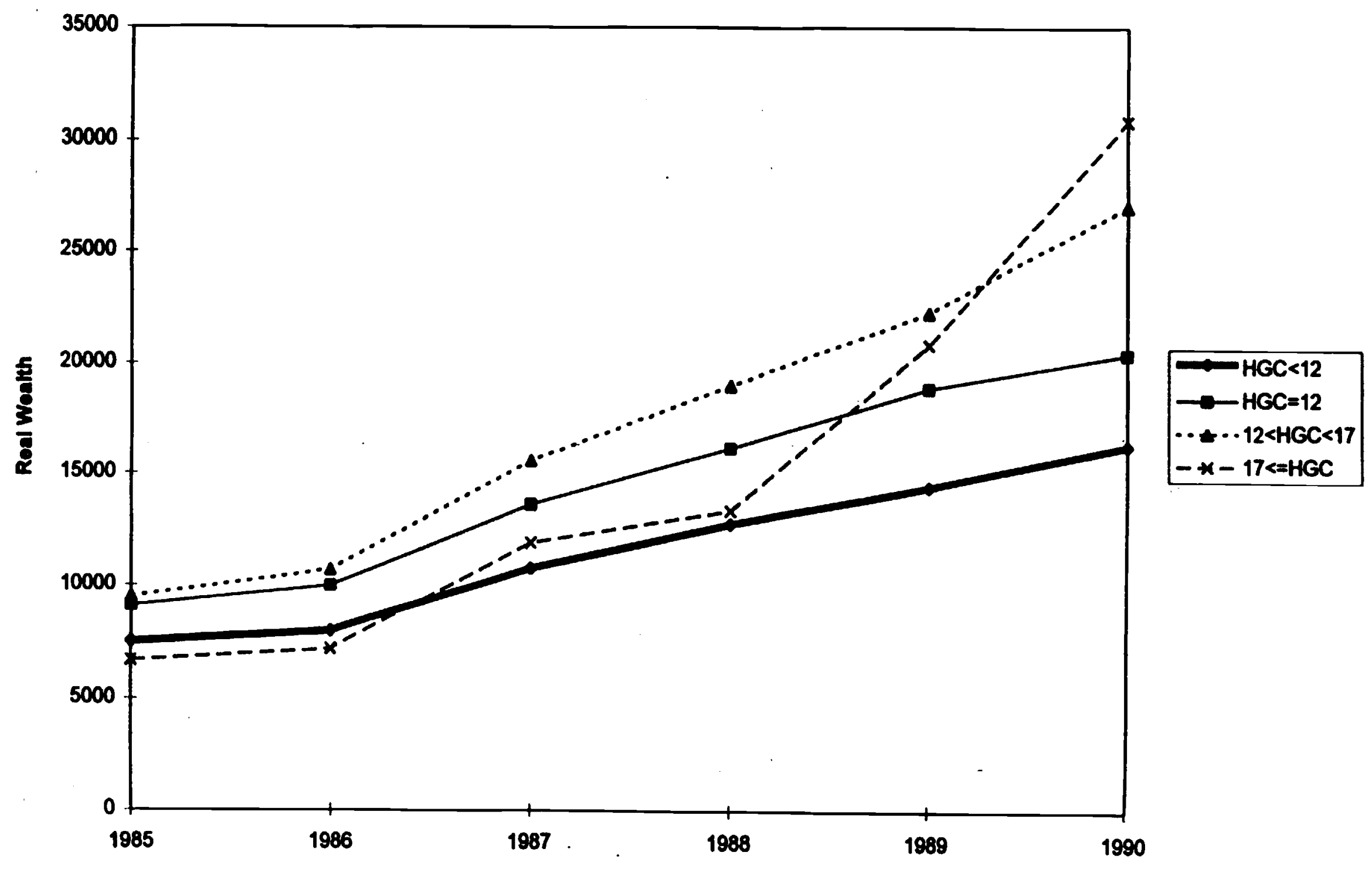


Figure 4: Mean Real Wealth by Four Categories of Aptitude Test Score

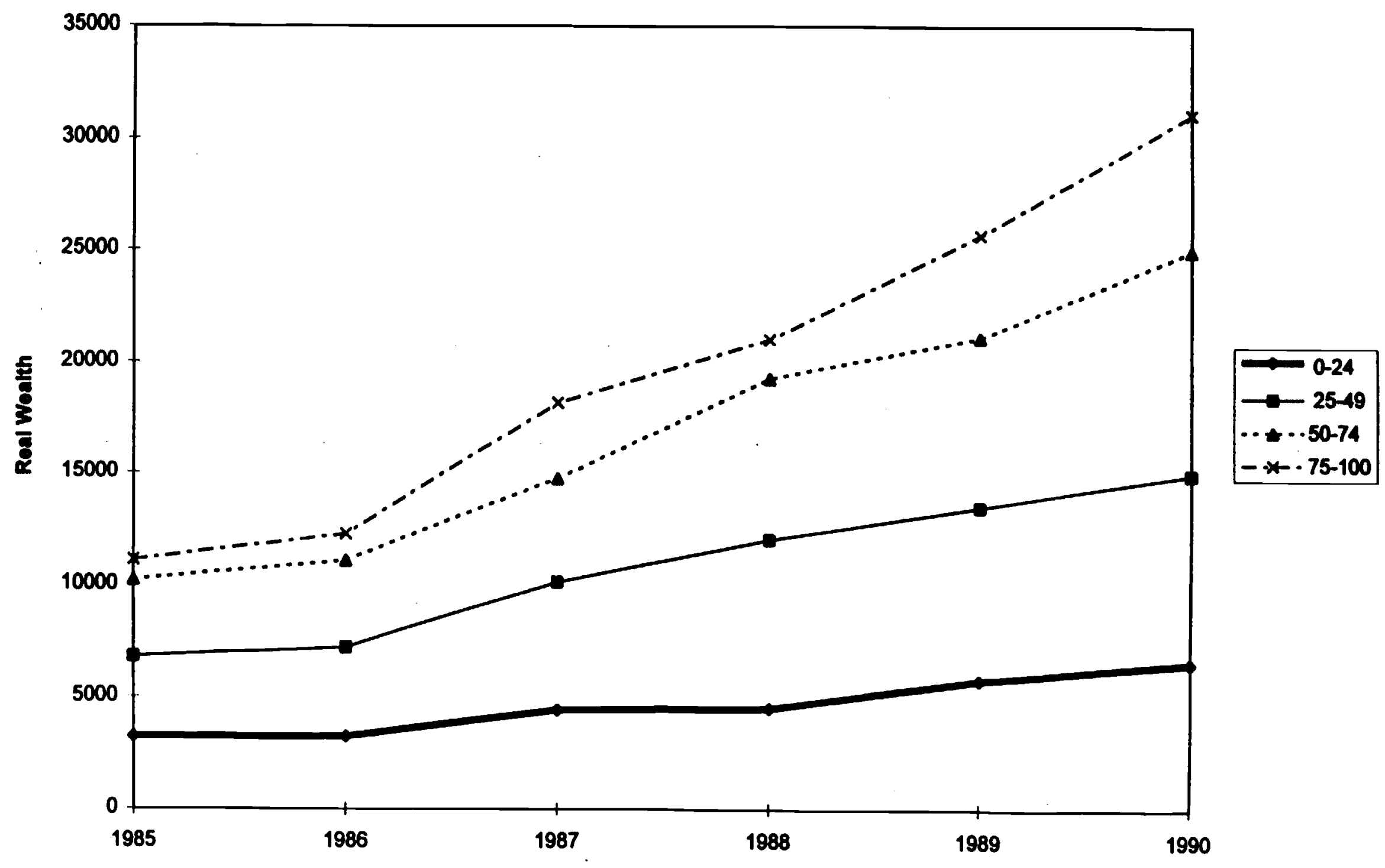


Figure 5: Mean Real Wealth by Four Categories of Respondent's 1990 Labor Supply: 1985-90

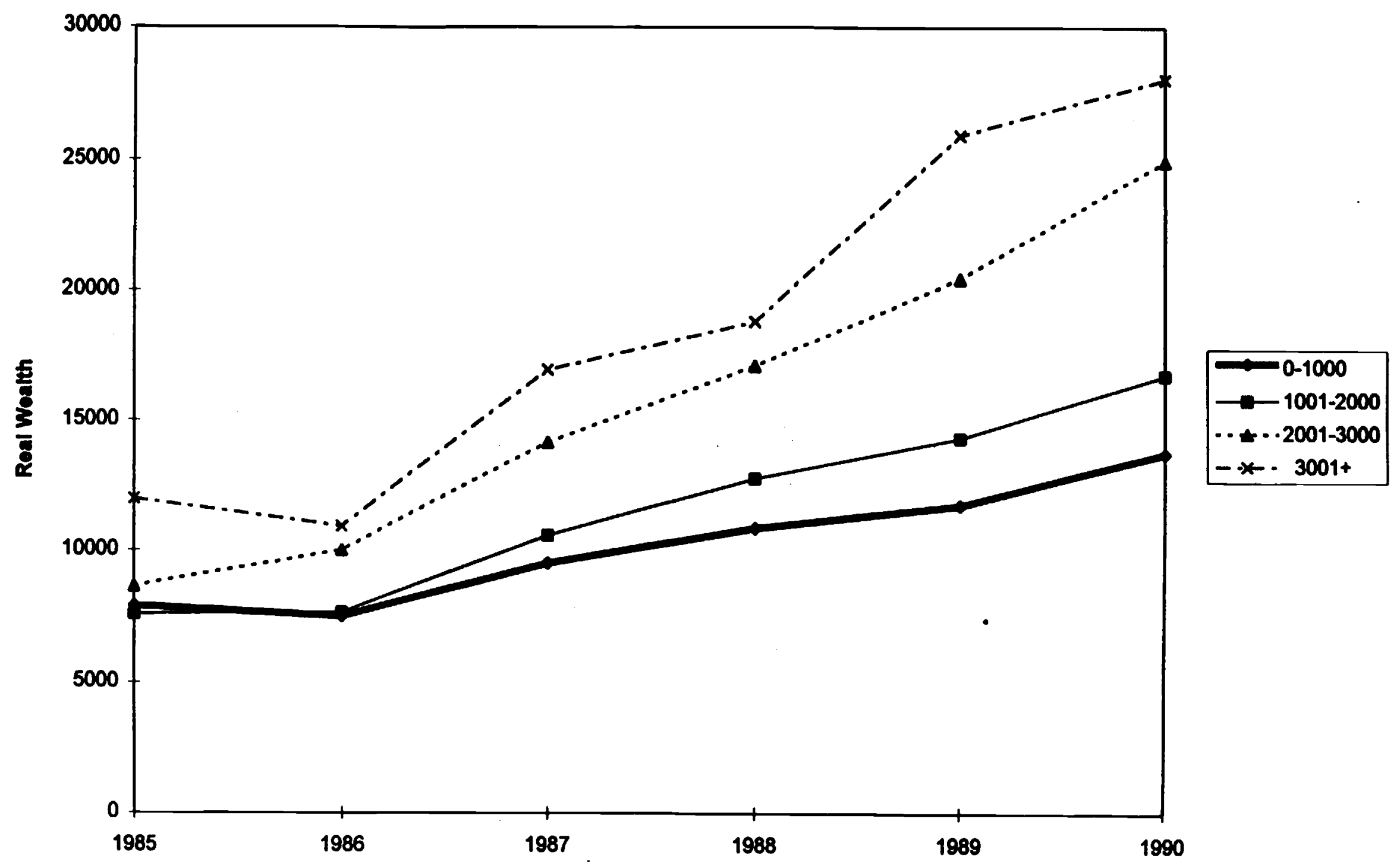


Figure 6: Renters' Mean Wealth by Four Categories of Real Constant-Quality House Price: 1985 Distribution of House Prices

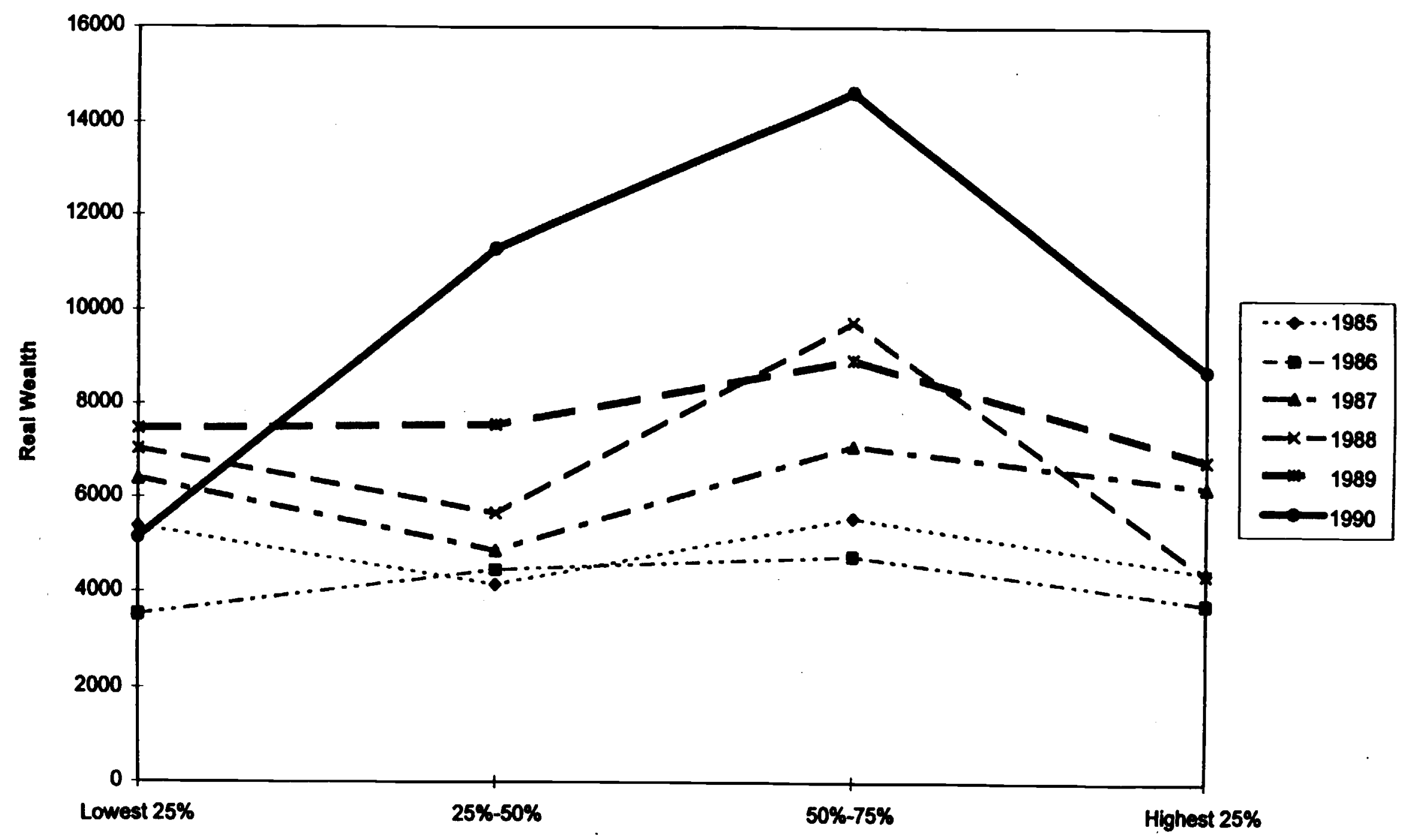


Figure 7: Homeownership Rates by Four Categories of Real Constant-Quality House Price:

1985 Distribution of House Prices

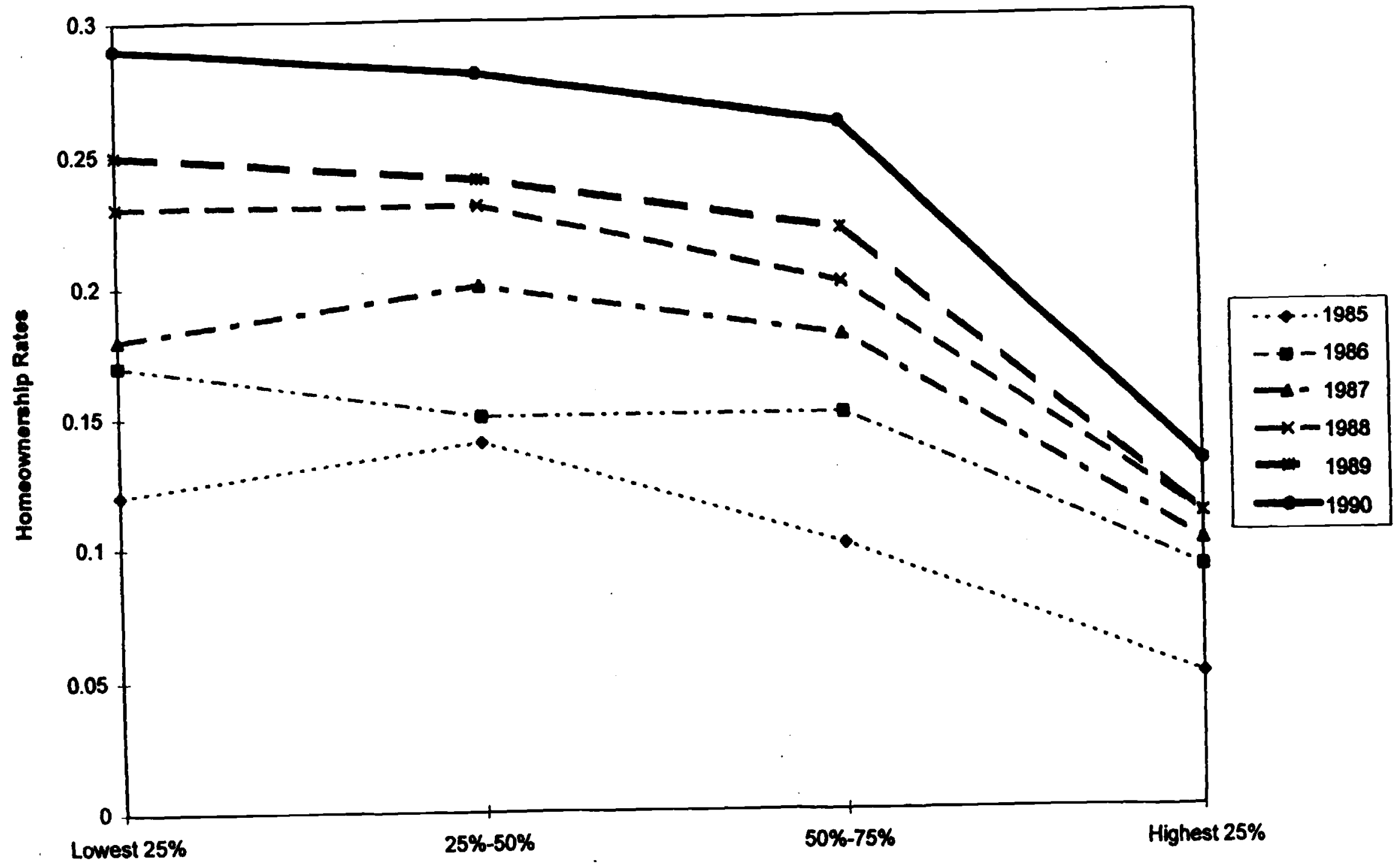


Figure 8: Renters' Marriage Rates by Four Categories of Real Constant-Quality House Price: 1985 Distribution of House Prices

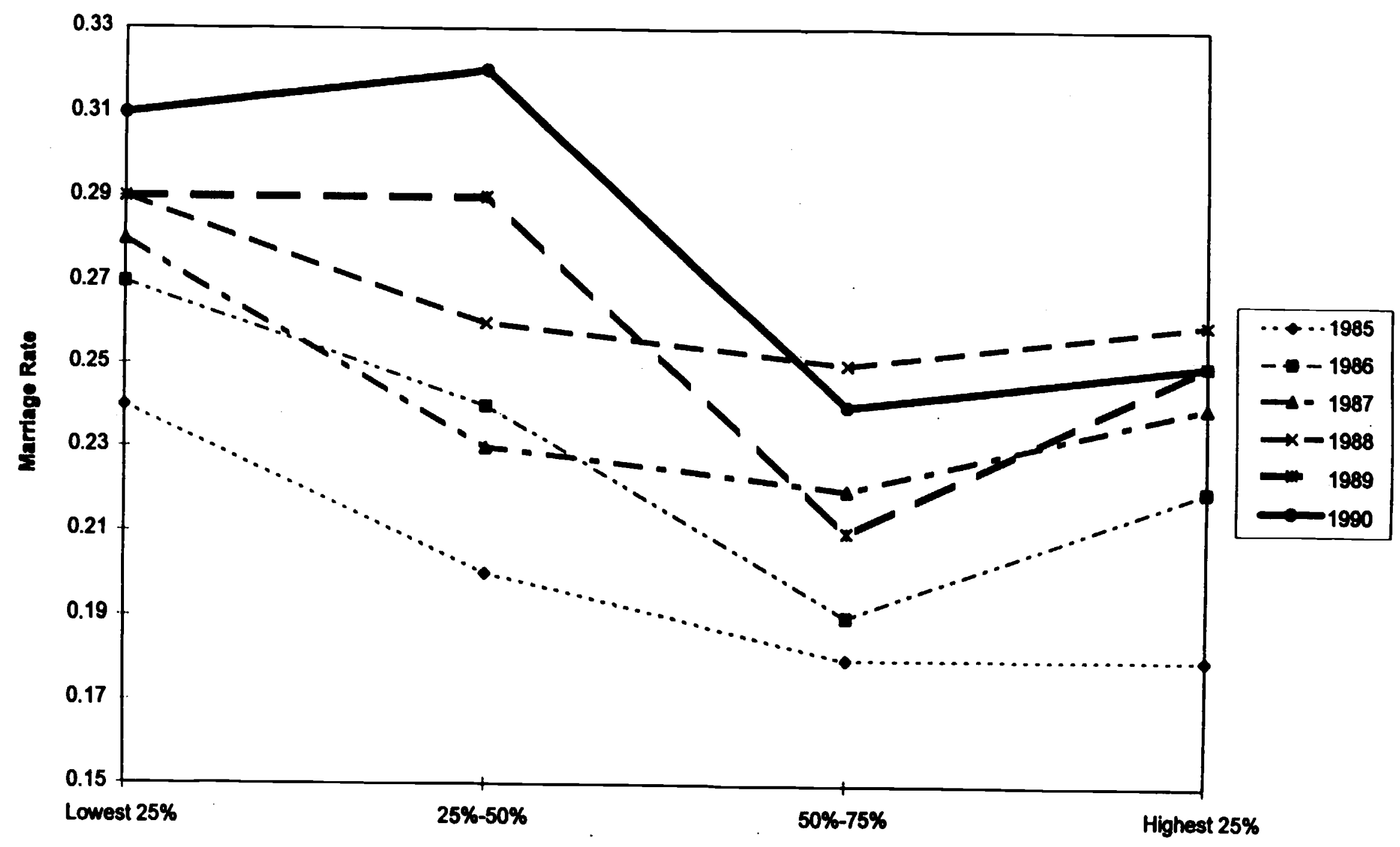


Figure 9: Real Rental Price of Housing by Four Categories of Real Constant-Quality House

Price: 1985 Distribution of House Prices

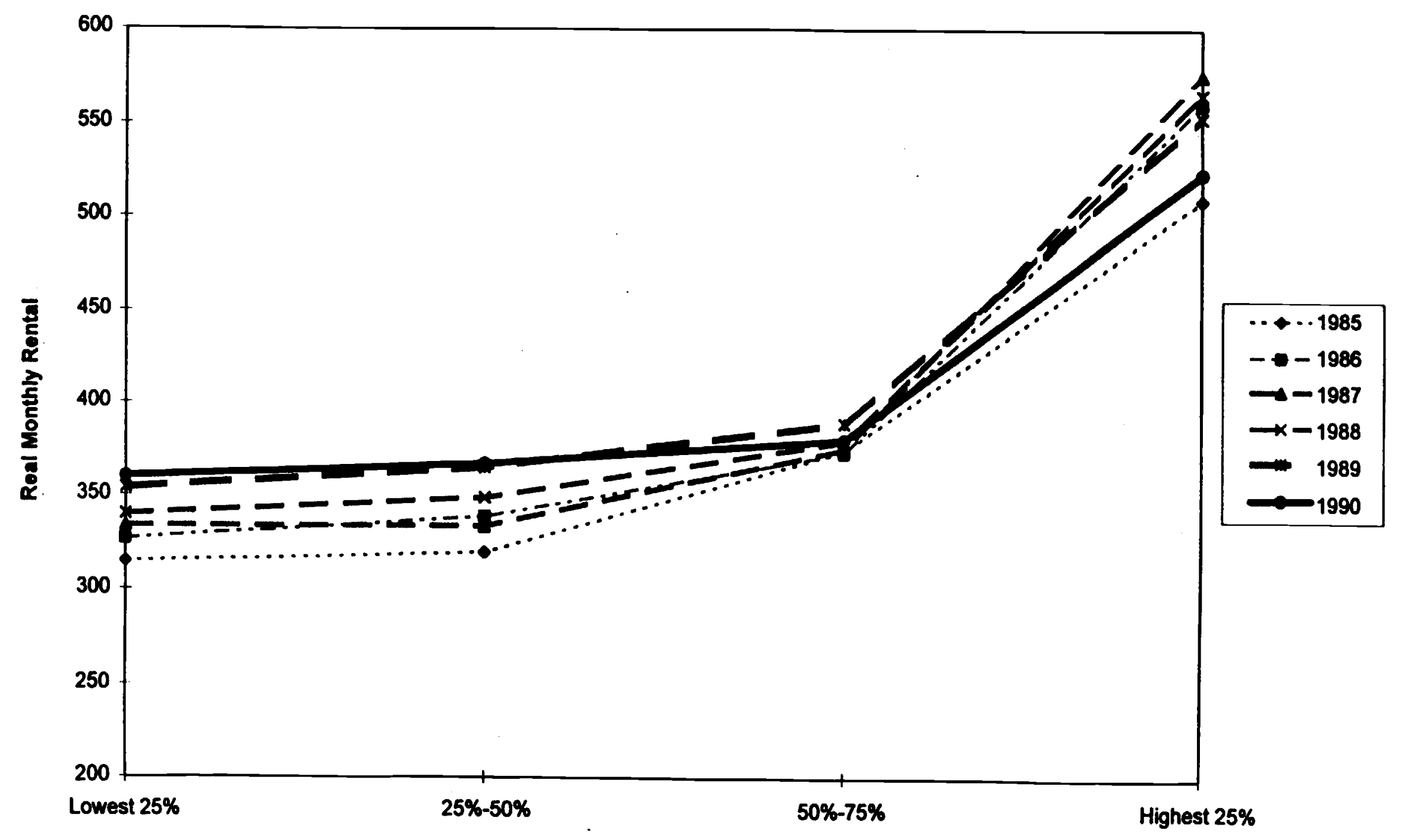

